\title{
HSF1 and HSPA6 as functional candidate genes associated with heat tolerance in Angus cattle
}

\section{Marielle Moura Baena ${ }^{1}$, Polyana Cristiane Tizioto², Sarah Laguna Conceição Meirelles ${ }^{3^{*}}$, Luciana Correia de Almeida Regitano ${ }^{4}$}

\footnotetext{
${ }^{1}$ Universidade Federal de Lavras, Programa de Pós-graduação em Zootecnia, Lavras, MG, Brazil.

${ }^{2}$ Universidade Federal de São Carlos, Programa de Pós-graduação em Genética Evolutiva e Biologia Molecular, São Carlos, SP, Brazil.

${ }^{3}$ Universidade Federal de Lavras, Departamento de Zootecnia, Lavras, MG, Brazil.

${ }^{4}$ Embrapa Pecuária Sudeste, São Carlos, SP, Brazil.
}

\begin{abstract}
The purpose of this study was to access and characterize single nucleotide polymorphisms (SNP) located within the HSF1 and HSPA6 candidate genes for adaptability in Angus breed raised in subtropical climate. Samples of DNA from 20 animals representing extreme phenotypes for adaptability traits were obtained. Sequence variations in the candidate genes were described by sequencing target regions. We identified 12 SNP located in the HSF1 gene. Moreover, four of the six SNP found in the HSPA6 gene cause amino acid substitutions in protein-coding regions. We also identified a representative SNP (called tag SNP) in a region of the HSF1 gene with high linkage disequilibrium $\left(\mathrm{r}^{2}=0.87\right)$ that may represent $11 \mathrm{SNP}$ located in this gene. Minor allele frequency observed for the SNP ranged from 0.10 to 0.50 and 0.02 to 0.21 for the HSF 1 and the HSPA6 genes, respectively. Overall, almost all SNP analyzed showed significant deviation from the Hardy-Weinberg Equilibrium and half of the loci had heterozygosity greater than 0.50 . The data suggest that there is sequence variability in these genes that could be exploited by breeding programs. There is genetic variation in HSF1 and HSPA6 genes in this populations of Angus breed, which is fundamental to obtain response to selection.
\end{abstract}

Key Words: Angus, molecular markers, thermoregulation

\section{Introduction}

According to the Instituto Brasileiro de Geografia e Estatística (IBGE, 2014), Brazil has the largest commercial cattle herd in the world with about 212 million animals, which places the country in the leading position as a beef exporter (ABIEC, 2014).

There is great concern about the thermal comfort of animals in Brazilian farming systems, due to the tropical climate of the country, characterized by high temperatures and solar radiation that can cause heat stress and affect the productive performance of the animals.

Heat stress provokes sorts of complex responses which are essential in the preservation of cell survival. In mammals, exposure to hypothermia or hyperthermia has been related to morphological and physiological alterations.

Received: December 8, 2016

Accepted: October 6, 2017

*Corresponding author: sarahlcmeirelles@gmail.com

Copyright (C) 2018 Sociedade Brasileira de Zootecnia. This is an Open Access article distributed under the terms of the Creative Commons Attribution License (http://creativecommons.org/licenses/by/4.0/), which permits unrestricted use, distribution, and reproduction in any medium, provided the original work is properly cited.
Bos indicus breeds are adapted to tropical environmental conditions, owing to their long-time adaptation with tropical climates in relation to taurine breeds; however, the meat from these animals have lower quality, particularly with regard to tenderness. The adverse effects of heat stress also affect the feed intake, milk production, growth rate, and reproduction which are lower in $B$. indicus than in B. taurus breeds (Gaughan et al., 2012).

To establish an economically viable farming system, it is necessary to look for breeds or individuals that have better genetic potential for adaptation to local environmental conditions and at the same time provide better quality beef.

The development of a breed of cattle that can tolerate heat stress and maintain productivity has been a long-term goal of researchers and cattle breeders. However, isolation of differences in thermoregulatory ability is challenging due to the many physical and genetic differences among bovines (Scharf et al., 2010).

Advances in molecular genetics have allowed the identification of genes and molecular markers related to adaptability, for example single nucleotide polymorphisms (SNP), that may be applicable in marker-assisted selection. Thus, to minimize problems related to heat stress, one 
strategy is to select animals with superior genetic potential for adaptation to tropical climates.

Some candidate genes have been indicated as associated with heat tolerance in cattle, including heat shock transcription factor 1 (HSF1) and heat shock $70 \mathrm{kDa}$ protein 6 (HSPA6) genes mapped to bovine chromosomes 14 and 3 (Zimin et al., 2009), respectively. These genes encode for heat shock proteins (HSP) that are involved in the reduction of cell damage caused by heat stress. The HSP are activated in response to stressors such as heat, physical strain, oxidative stress, among other factors. These proteins are released intracellularly and extracellularly in an inducible form in response to stress (Hecker and McGarvey, 2011).

Under stressful conditions, such as temperature rise, HSP levels are high, aiding the synthesis and maturation of new proteins that will replace those affected by stress. Heat shock proteins also provide a subsidy for cells to identify and facilitate the refolding of damaged proteins or to target them to a suitable proteolytic system, facilitating the elimination of proteins whose damage is not amenable to restoration. The increase of HSP in the damaged cells, besides helping in the repair of proteins, plays an important role in the maintenance of the viability, since it inhibits the apoptosis (Deb et al., 2014).

Among these proteins, the family HSP70 has a significant role in cell thermotolerance (Beckham et al., 2004) and animal survival (King et al., 2002). This family is the most conserved phylogenetically and of major importance for the folding of proteins in the cells. Therefore, it is known as the protein with the highest performance in response to cellular stress, being used in many studies as a stress indicator (Cole and Meyers, 2011; Monzo et al., 2012).

This study aimed to resequence the candidate genes HSF 1 and HSPA6 to identify and characterize SNP related to adaptability in Angus cattle raised in a subtropical climate.

\section{Material and Methods}

The animals used in this study came from a farm under the ownership of Casa Branca Agropastoril Ltda., in the municipality of Silvianópolis, MG, Brazil. This region is at latitude $22^{\circ} 01^{\prime} 46^{\prime \prime} \mathrm{S}$, longitude $45^{\circ} 50^{\prime} 06^{\prime \prime} \mathrm{W}$, and altitude of $897 \mathrm{~m}$ and it is characterized by a wet subtropical climate with mean annual temperature of $19.9^{\circ} \mathrm{C}$.

Seventy-two Angus bulls of 15 months of age were raised in feedlot system, where they received water and commercial ration in covered trough and had access to shade.
The animals were herded into a cattle handling corral $12 \mathrm{~h}$ before the beginning of measurements of characteristics. In this period, the animals remained without access to shade, water, and food. They were taken to a covered trunk, one by one, to remain under the sun as long as possible before measurements.

Adaptability measures, respiratory rate (RR), and coat temperature (CT) were collected once a month for five consecutive months, from July to November 2012 at two different times: 7:00 and 13:00 h.

The respiratory rate was obtained by counting twice the number of breaths in the flank region in a period of $15 \mathrm{~s}$ and the average of these values was multiplied by four to obtain the number of breaths per minute. The coat temperature was measured in ${ }^{\circ} \mathrm{C}$ by a digital infrared thermometer targeted $20 \mathrm{~cm}$ below the vertebral column of the animal (Silva, 2000; Eustáquio Filho et al., 2011).

From a total of 72 animals, 20 presenting extreme phenotypes for adaptability traits such as RR and CT were selected for the target-resequencing and for identification of molecular markers.

The averages of the respiratory rate and the early afternoon coat temperatures were obtained to calculate an index, in which each trait corresponded to 0.50 of the index. This index was generated for each animal containing the two traits (RR and CT).

Animals were considered extreme "negative" if they were less tolerant to heat and "positive" if they were more tolerant to heat, based on the classification of the index obtained. Therefore, the ten highest values were classified as negative and the ten smallest values as extreme positive phenotypes. The phenotype information was used to perform a Fisher's exact test to determine if allele frequencies differed among extreme animals.

Genomic DNA was extracted from blood samples $(5 \mathrm{~mL})$ as described in Regitano and Coutinho (2001). Concentration of DNA was measured by spectrophotometry and the quality was verified by the 260:280 ratio. The DNA integrity was assessed by electrophoresis in agarose gel.

FASTA sequences of HSF1(Gene ID: 506235) and HSPA6 (Gene ID: 539835) genes were obtained from the public database National Center for Biotechnology Information (NCBI). Primers were designed for target regions using Primer 3 Plus software, available online (http://www.bioinformatics.nl/cgi-bin/primer3plus/ primer3plus.cgi). Sequence variations in the candidate genes were described by sequencing target regions.

Forward $(\mathrm{F})$ and reverse $(\mathrm{R})$ primers were designed for the amplification of HSF1 and HSPA6 genes (Table 1), as well as their amplicon size $(\mathrm{pb})$ and annealing temperatures $\left({ }^{\circ} \mathrm{C}\right)$. 
Reactions to amplify all target regions were carried out with final volume of $20 \mu \mathrm{L}$ : 80ng of the DNA template, $0.165 \mu \mathrm{M}$ of each primer, $1.5 \mathrm{mM}$ of the reaction buffer with $\mathrm{MgCl}_{2}, 0.2 \mathrm{mM}$ of each dNTP, and 0.650 unit of the Taq DNA polymerase. Polymerase chain reactions (PCR) were performed in a thermocycler model T100 (Bio-Rad) using a standard PCR program. The denaturation step of $95{ }^{\circ} \mathrm{C}$ for $3 \mathrm{~min}$ was followed by 35 cycles at $94{ }^{\circ} \mathrm{C}$ for $40 \mathrm{~s}$, annealing temperature according to each primer pair for $30 \mathrm{~s}$, and final extension of $72{ }^{\circ} \mathrm{C}$ for $50 \mathrm{~s}$. Finally, PCR products were visualized in agarose gel and then purified using a ExoSAP-IT enzyme following manufacturer's protocol.

The sequencing reactions were performed as described by Tizioto et al. (2013) using the ABI Prism BigDye Terminator v. 3.1 cycle sequencing kit. To avoid any potential contamination, sequencing products were purified using isopropanol and sodium acetate. The sequences were processed in an ABI Prism 3100 Avant.

The PhredPhrapConsed package (Ewing and Green, 1998) was used to identify SNP in the extreme-phenotype animals sequenced. The SNP locations were determined by mapping sequences to the FASTA files of the gene.

We predicted potential functional consequences of the variants by inspecting amino acid substitution and open reading frame changes with Gene Runner software (http://www.generunner.net).

Table 1 - Description of the primers used for amplification of HSF1 and HSPA6 genes in cattle

\begin{tabular}{|c|c|c|c|}
\hline Primer & $5^{\prime}-3^{\prime}$ sequence & $\begin{array}{l}\text { Amplicon } \\
\text { size }(\mathrm{pb})\end{array}$ & $\begin{array}{c}\text { AT } \\
\left(\mathrm{C}^{\circ}\right)\end{array}$ \\
\hline & HSF1 gene & & \\
\hline Region1_F & TCCTTTTGGGGTCTTAGCCG & & \\
\hline Region1_R & AGGCACCTGGTAGAAAGCAG & 845 & 57.5 \\
\hline Region2_F & CTGCGGAGCGAGGACATAAA & & \\
\hline Region2_R & CCAAGGCCACCTAATCCCAC & 877 & 59.5 \\
\hline Region3_F & TCTGACCCCCTAAAGGCACA & & \\
\hline Region3_R & CGCACCTCTCGTCTACACTC & 879 & 59.5 \\
\hline Region4_F & CTGTTCAGCCCCTCGGTTAC & & \\
\hline Region4_R & CCTGGCTCATCGGTCTGTTT & 780 & 59.5 \\
\hline Region5_F & CTGTCTGTCCTACCACCCCA & & \\
\hline \multirow[t]{2}{*}{ Region5_R } & CATGGCTTGTCAGCATGGTC & 795 & 57.5 \\
\hline & HSPA6 gene & & \\
\hline Region1_F & GGTCTCCCGCAACTGGATAAA & & \\
\hline Region1_R & GATTCTCAGGACGTTGAGCCC & 703 & 57.7 \\
\hline Region2_F & TAATCACGGTGCCTGCCTAC & & \\
\hline Region2_R & GTAGTCATCACCCCACCAGC & 808 & 59.5 \\
\hline Region3_F & GGCAGGGAGCTGAACAAAAG & & \\
\hline Region3_R & GTCTTGTACTTTGCGCCTGTC & 651 & 57.7 \\
\hline Region4_F & GTGGAGAGGATGGTTCGTGAG & & \\
\hline Region4_R & AGGGTAAGATTCTCCTCCACTC & 500 & 59.7 \\
\hline
\end{tabular}

Minor allele frequencies (MAF), identification of TagSNP, linkage disequilibrium (LD) extends and heterozygosity, and Hardy Weinberg equilibrium deviations were obtained using Haploview software (Barrett et al., 2005).

Fisher's exact test was applied to determine if allele frequencies differed among extreme phenotypes, by comparing genotype frequencies at each extreme using SAS software (Statistical Analysis System, version 9.2).

\section{Results}

The general averages estimated for RR and CT were 55.77 and 29.48, respectively. There was a significant difference between the morning and afternoon periods with values of 48.13 (RR, morning), 58.70 (RR, afternoon), and 28.08 (CT, morning), 31.05 (CT, afternoon).

Twelve SNP were identified in HSF1 gene; eight of these were mapped to coding regions, but they do not alter the amino acid sequence of the protein. The other markers identified were located in intron with uncharacterized function (Table 2).

From the SNP found in the exon of HSPA6 gene, only two (4 and 6) are synonymous mutations (Table 3). While SNP1 changes the amino acid alanine into serine, SNP2 changes histidine into glutamine, SNP3 replaces isoleucine by phenylalanine, and SNP5 modifies proline into alanine.

Among the markers identified, we found a TagSNP (SNP3) in the HSF1 gene (Figure 1). This polymorphism represents a set of SNP mapped physically close in the chromosome and, therefore, tend to have the same behavior in cell division. The haplotype formed by the SNP 6 and 11 showed a strong degree of LD with a maximum $r^{2}$ value of 0.87 .

Table 2 - Description of single nucleotide polymorphisms (SNP) of HSF1 gene

\begin{tabular}{lccccc}
\hline SNP & $\begin{array}{c}\text { Gene location } \\
\text { (base pairs) }\end{array}$ & $\begin{array}{c}\text { Gene } \\
\text { region }\end{array}$ & $\begin{array}{c}5^{\prime}-3^{\prime} \\
\text { sequence }\end{array}$ & $\begin{array}{c}\text { Consensus } \\
\text { nucleotide }\end{array}$ & $\begin{array}{c}\text { Mutant } \\
\text { nucleotide }\end{array}$ \\
\hline 1 & 15.029 & intron & CACCCCCAG & C & A \\
2 & 15.011 & intron & AGAGGTAC & G & A \\
3 & 15.009 & intron & AGGTACGTC & A & C \\
4 & 15.511 & exon & GCGTCCTTC & C & T \\
5 & 15.954 & intron & CACGTGGG & T & A \\
6 & 17.384 & exon & GCAAGCAA & C & T \\
7 & 19.842 & exon & CCGGCACTT & C & G \\
8 & 19.841 & exon & CGGCACTTC & A & G \\
9 & 19.832 & exon & GGGTCCACT & C & A \\
10 & 19.727 & exon & TGGTCCGGA & C & T \\
11 & 19.728 & exon & GTGGTCCGG & T & C \\
12 & 19.788 & exon & CCCCCGGTG & C & T \\
\hline A - adenine; & C - cytosine; G - guanine; - thymine. & &
\end{tabular}

A - adenine; $\mathrm{C}$ - cytosine; $\mathrm{G}$ - guanine; $\mathrm{T}$ - thymine. 
For the HSPA6, we found a weaker LD degree and it was not possible to construct haplotypes.

Single nucleotide polymorphisms 1, 2, 3, 4, 8, and 11 of HSF 1 gene showed high degree of heterozygosity, with values above 0.70 (Table 4). In addition, markers 5 , 6 , and 9 of HSF 1 gene and all SNP found in HSPA6 gene showed low level of heterozygosity, with values below 0.50 (Table 4).

In this study, only two types of genotypes for all SNP of both genes were found. For example, in SNP1 of the HSF1 gene, only GG and GT genotypes were found between the animals and the same for the other SNP in this gene and also in HSPA6 gene.

The MAF observed for SNP of HSF1 gene ranged from 0.10 to 0.50 and of HSPA6, from 0.02 to 0.21 (Table 4).

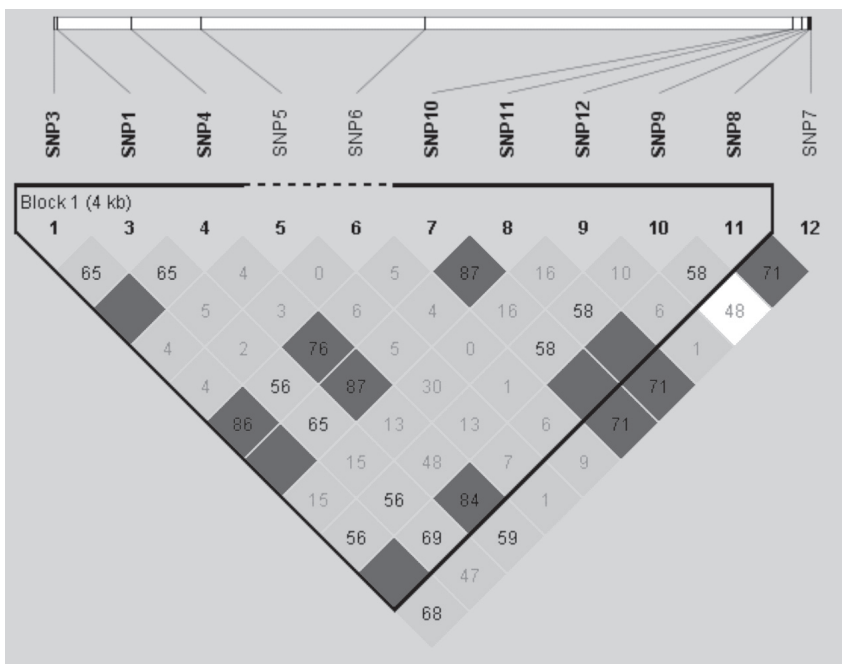

SNP - single nucleotide polymorphisms.

The black shading represents "strong linkage disequilibrium", gray shading evidence "genetic recombination", and white square represents "with no statistical evidence".

Figure 1 - Linkage disequilibrium pattern $\left(\mathrm{r}^{2}\right)$ among the SNP identified in the HFS1 gene.

Table 3 - Description of single nucleotide polymorphisms of HSPA6 gene

\begin{tabular}{ccccccc}
\hline & $\begin{array}{c}\text { Gene } \\
\text { SNP location } \\
(\mathrm{bp})\end{array}$ & $\begin{array}{c}\text { Gene } \\
\text { region }\end{array}$ & $\begin{array}{c}5^{\prime}-3^{\prime} \\
\text { sequence }\end{array}$ & $\begin{array}{c}\text { Consensus } \\
\text { nucleotide nucleotide }\end{array}$ & $\begin{array}{c}\text { Mutant } \\
\text { substitution }\end{array}$ \\
\hline 1 & 1.564 & exon & TCCGGAA & G & T & S instead of A \\
2 & 1.287 & exon & GTCCACT & C & G & Q instead of H \\
3 & 1.195 & exon & TTTATCTC & A & T & F instead of I \\
4 & 2.040 & exon & CAGCTTC & C & T & $*$ \\
5 & 2.002 & exon & GTCCTCC & C & G & A instead of P \\
6 & 2.451 & exon & CTGTGGT & T & A & $*$ \\
\hline
\end{tabular}

A - adenine; C - cytosine; $\mathrm{G}$ - guanine; $\mathrm{T}$ - thymine; $\mathrm{S}$ - serine; $\mathrm{A}$ - alanine; $\mathrm{Q}$ glutamine; $\mathrm{H}$ - histidine; $\mathrm{F}$ - phenylalanine; I - isoleucine; $\mathrm{P}$ - proline.

* Without amino acid change.

\section{Discussion}

The SNP (Table 2) can be silent mutations which changed the nucleotide, but not the amino acid in the protein. These mutations, also called even synonymous mutations, can affect the level of protein expression and other events of the protein formation process. According to Curi (2004), these mutations can promote alternative RNA processing and modify the open reading frame. Synonymous mutations are often overlooked in genetic analyses for disease-causing mutations unless they are directly associated with potential splicing defects. Several studies indicate that some SNP are associated with changes in protein expression and also protein folding and function. The effect of codon usage and mRNA structural changes in protein translation rates and how they can affect protein structure and function is beginning to be studied. Bartoszewski et al. (2016) stated that these synonymous mutations can alter the translational kinetics and protein folding and/or function and the mechanism of how this occurs is based on a model in which codon usage modulates the translational rate by introducing pauses caused by nonoptimal or rare codons or by introducing changes in the mRNA structure, which influences co-translational folding. Parmley et al. (2006) showed that silent mutations affected stability of the secondary structure of the mRNA in mammals.

Table 4 - Hardy Weinberg equilibrium (HWE) and heterozygosity (He) deviations, minor common allele frequencies (MAF), and P-values of Fisher's exact test performed for HSF1 and HSPA6 genes

\begin{tabular}{lllcc}
\hline SNP & HWE & He & MAF & P-value \\
\hline \multicolumn{5}{c}{ HSF1 gene } \\
1 & 0.0061 & 0.85 & 0.42 & 0.4945 \\
2 & 0.0000 & 1.00 & 0.50 & - \\
3 & 0.0245 & 0.92 & 0.46 & 0.6429 \\
4 & 0.0034 & 0.93 & 0.46 & 0.6667 \\
5 & 1.0000 & 0.06 & 0.03 & 0.6667 \\
6 & 1.0000 & 0.06 & 0.03 & 0.6250 \\
7 & 0.4218 & 0.61 & 0.30 & 0.2720 \\
8 & 0.1103 & 0.81 & 0.38 & 0.4895 \\
9 & 0.6678 & 0.20 & 0.26 & 0.4079 \\
10 & 0.0660 & 0.53 & 0.37 & 0.3709 \\
11 & 0.0264 & 0.76 & 0.40 & 0.4821 \\
12 & 1.0000 & 0.61 & 0.10 & 0.2637 \\
& & HSPA6 gene & \\
1 & 1.0000 & 0.43 & 0.21 & 0.3427 \\
2 & 1.0000 & 0.35 & 0.17 & 0.4196 \\
3 & 1.0000 & 0.33 & 0.16 & 0.3394 \\
4 & 1.0000 & 0.26 & 0.13 & 0.3251 \\
5 & 1.0000 & 0.05 & 0.02 & 0.5263 \\
6 & 1.0000 & 0.25 & 0.12 & 0.4308 \\
\hline
\end{tabular}


Other authors also claim that, although SNP mapped to intergenic regions do not alter amino acid sequencing, they may be regulatory mutations playing an important role in the regulation and processing of mRNA (Zan et al., 2007).

However, the SNP in the coding region of HSP genes could affect peptide-binding kinetics or affinity of the HSP proteins and ATPase activity (Table 3), while nucleotide changes in the flanking regions (promoter and 5', 3' untranslated region (UTR)), as already mentioned, might affect inducibility, degree of expression, or stability of HSP mRNA (Bernabucci et al., 2009).

According to Curi (2004), non-synonymous mutations can cause a dysfunction of the protein and, consequently, phenotypic variation. Thus, SNP found in this study may be important for formation, function, and expression of HSP proteins and future association studies using the SNP identified may be useful to develop strategies to implement marker-assisted selection for heat stress and tolerance in breeding programs of Angus breed.

In humans, HSP70 gene polymorphism in the coding region was positively associated with human longevity and survival advantage and was associated with an increased ability to respond to heat stress (Singh et al., 2006). Similarly, adaptation to different thermal conditions was associated with the specific SNP of HSP90 in ovine species (Salces-Ortiz et al. 2013).

Schwerin et al. (2003) reported the association of the SNP within HSP70 promoter to the shorter productive life in dairy cattle. Previous studies highlighted the role of polymorphism within HSP70 promoter region to the reproductive parameters including pregnancy rate, calf weaning weights, and fertility in dairy cattle (Banks et al., 2007; Starkey et al., 2007; Rosenkrans et al., 2010).

Li et al. (2011), while studying Holstein cows, found SNP associated with heat tolerance located at $900 \mathrm{pb}$ and 4693 bp of HSF1 gene. Furthermore, Liu et al. (2010) and Adamowicz et al. (2005), also studying Holstein cows, found SNP in regulatory regions in other genes (HSP70A1A and ATPIA1, respectively) related to thermoregulation.

Li et al. (2010) also identified five novel SNP (one in CDS and four in 3'-UTR) and 11 different genotypes in HSP70.1 gene of Chinese Holstein cattle. Among these, three genotypes (AB, DD, and FF) showed higher potassium content in erythrocytes, higher milk fat and protein percentage, and higher milk yield, respectively. Thus, the authors suggested the probable associations of these genotypes with thermotolerance. Zhang et al. (2002) detected polymorphisms of the regulatory and coding regions of the HSP70 gene associated with different heat tolerance capabilities in broiler chickens. Huang et al. (2002) detected SNP in the 5' flanking region of the HSP70.2 gene in boars and these SNP were found to be associated with semen quality traits including sperm motility, percentage of normal and abnormal sperms, sperm concentration, and semen volume. In pigs, a functional promoter and 3'-UTR variants of highly conserved inducible HSP70.2 gene significantly affected mRNA stability and cell response to stress (Schwerin et al. 2001, 2002).

The protein produced by HSP70A1A gene, a member of HSP70 family, is the main chaperone acting on a body subjected to heat stress. Homologous to this gene, HSPA6 may also act in severe conditions of heat stress. Mohanarao et al. (2013) observed an increase of 14.4 times in the expression of this gene when goats were exposed to high temperatures.

As observed, few reports have identified SNP within heat shock protein gene contributing to certain disease susceptibility and stress tolerance in B. Taurus and those found were related to dairy breeds. However, more studies should be reported on genetic variants and their characterization, as well as the associated with heat tolerance in Angus cattle.

Linkage disequilibrium refers to the non-random association of alleles of different loci (McKay et al., 2007). The higher the LD between SNP, the greater the chance of these SNP be inherited together during cell meiosis. Li et al. (2011), studying Holstein cattle in China, found two haplotypes in HSF1 gene, but with weak LD between polymorphisms $\left(r^{2}=0.10\right)$. The LD differences between breeds and populations may influence the marker effects of this gene.

Strong LD was found in 0.2222 pairs of SNP (black shading, Figure 1). However, 0.7778 pairs of SNP (gray shading, Figure 1) may indicate genetic recombination. Interestingly, a few pairs of SNP with evidence of recombination (for example: SNP1 with SNP3 and SNP9 with SNP8) are neighbors. This fact can be explained by the occurrence of gene conversion.

Most of the SNP identified presented significant deviation from Hardy Weinberg equilibrium. This implies that there was a significant difference in genotype and allele frequencies within each gene locus, as well as the occurrence of inbreeding flow or genes from other populations (Table 4). It is important to consider that the sample size may be influencing these results as well as the sampling strategy of extreme phenotypes.

The equilibrium of a gene can be affected by factors such as mutation, migration, genetic drift, and selection because they promote changes in genotypic and allelic frequencies of a gene through generations. Li et al. (2011) also observed 
deviations from equilibrium for both polymorphisms found in HSF1 gene.

Single nucleotide polymorphisms of HSF1 gene with high degree of heterozygosity (Table 4) can be considered a measure of genetic variability, which is fundamental to obtain response to selection. According to Ott (1992), marker heterozygosity above 0.70 is considered high polymorphism.

The markers with low level of heterozygosity, with values below 0.50 , can be indicating moderate variability of genetic markers in the genes analyzed (Table 4).

Association studies commonly consider markers with MAF above 0.10. Thus, in HSPA6 gene, some SNP may not be appropriate for use in marker-assisted selection (Table 4).

Values of MAF, deviation from Hardy Weinberg equilibrium, and observation of only two genotypes must have been observed because of the strategy chosen of sampling phenotypic extreme animals. The lack of prior association between phenotypes and genotypes may be due to biased allelic frequency and to small size of sequenced animals.

\section{Conclusions}

There is genetic variation in HSF1 and HSPA6 genes in this populations of Angus breed, which is fundamental to obtain response to selection.

\section{Acknowledgments}

The authors wish to thank the producers of the farm Casa Branca Agropastoril Ltda. for providing phenotype data used in this study. We also thank the Fundação de Amparo à Pesquisa do Estado de Minas Gerais (FAPEMIG) for providing scholarships and financial support to the project.

\section{References}

Adamowicz, T.; Pers E. and Lechniak, D. 2005. A New SNP in the 30-UTR of the Hsp70-1 Gene in Bos taurus and Bos indicus. Biochemical Genetics 43:623-627.

ABIEC - Associação Brasileira das Indústrias Exportadoras de Carne. 2014. Exportações brasileiras de carne bovina. Available at: $<$ http://www.abiec.com.br/41_exportacao_ano.asp $>$. Accessed on: Oct. 12, 2014.

Banks, A. 2007. Identification of single nucleotide polymorphisms within the promoter region of the bovine heat shock protein 70 gene and associations with pregnancy. American Society of Animal Science, Southern Section Meeting 85:10.

Bartoszewski, R.; Króliczewski, J.; Piotrowski, A.; Jasiecka, A. J.; Bartoszewska, S.; Vecchio-Pagan, B.; Fu, L.; Sobolewsk, A.; Matalon, S.; Cutting, G. R.; Rowe, S. M. and Collawn, J. F. 2016. Codon bias and the folding dynamics of the cystic fibrosis transmembrane conductance regulator. Cellular \& Molecular Biology Letters 21:23.
Barrett, J. C.; Fry B.; Maller, J. and Daly, J. M. 2005. Haploview: analysis and visualization of $\mathrm{LD}$ and haplotype maps. Bioinformatics 21:263-265.

Beckham, J. T.; Mackanos, M. A.; Crooke, C.; Takahashi T.; O'Connell-Rodwell, C.; Contag, C. H. and Jansen, E. D. 2004. Assessment of cellular response to thermal laser injury through bioluminescence imaging of heat shock protein 70 . Photochemistry and Photobiology 79:76-85.

Bernabucci, U.; Lacetera, N.; Danieli, P. P.; Bani, P.; Nardone, A. and Ronchi. B. 2009. Influence of different periods of exposure to hot environment on rumen function and diet digestibility in sheep. International Journal of Biometeorology 53:387-395.

Cole, J. A. and Meyers, S. A. 2011. Osmotic stress stimulates phosphorylation and cellular expression of heat shock proteins in rhesus macaque sperm. Journal of Andrology 32:402-410.

Curi, R. A. 2004. Relação entre os polimorfismos de genes envolvidos no controle do crescimento e na composição da carcaça e características de produção de bovinos de corte no modelo biológico superprecoce. Tese (D.Sc.). Instituto de Biociências da Universidade Estadual Paulista, Botucatu.

Deb, R.; Sajjanar, B.; Singh, U.; Kumar, S.; Singh, R.; Sengar, G. and Sharma, A. 2014. Effect of heat stress on the expression profile of Hsp90 among Sahiwal (Bos indicus) and Frieswal (Bos indicus $\times$ Bos taurus) breed of cattle: A comparative study. Gene 536:435-440.

Eustáquio Filho, A.; Teodoro, S. M.; Chaves, M. A.; Santos, E. F.; Silva, W. R.; Murta, R. M.; Carvalho, G. G. P. and Souza, L. E. B. 2011. Zona de conforto térmico de ovinos da raça Santa Inês com base nas respostas fisiológicas. Revista Brasileira de Zootecnia 40:1807-1814

Ewing, B. and Green, P. 1998. Base-calling of automated sequencer traces using phred. II. Error probabilities. Genome Research 8:186-194

Gaughan, J. B.; Bonner, S. L.; Loxton, I. and Mader, T. L. 2012. Effects of chronic heat stress on plasma concentration of secreted heat shock protein 70 (Hsp70) in growing feedlot cattle. Journal of Animal Science 90:2988-2994.

Hecker, J. G. and McGarvey, M. 2011. Heat shock proteins as biomarkers for the rapid detection of brain and spinal cord ischemia: A review and comparison to other methods of detection in thoracic aneurysm repair. Cell Stress and Chaperones 16:119-131.

Huang, S. Y.; Chen, M. Y.; Lin, E. C.; Tsou, H. L.; Kuo, Y. H.; Ju, C. C. and Lee, W. C. 2002. Effects of single nucleotide polymorphisms in the $5^{\prime}$-flanking region of heat shock protein 70.2 gene on semen quality in boars. Animal Reproduction Science 70:99-109.

IBGE - Instituto Brasileiro de Geografia e Estatística. 2014. Pesquisas trimestrais do abate de animais, do leite, do couro e da produção de ovos de galinha. Available at: <http://www.ibge.gov.br/home/>. Accessed on: Mar. 25, 2014.

King, Y. T.; Lin, C. S.; Lin, J. H. and Lee, W. C. 2002. Wholebody hyperthermia-induced thermotolerance is associated with the induction of Heat Shock Protein 70 in mice. Journal of Experimental Biology 205:273-278.

Li, Q.; Han, J.; Du, F.; Ju, Z.; Huang, J.; Wang, J.; Li, R.; Wang, C. and Zhong, J. 2010. Novel SNPs in HSP70A1A gene and the association of polymorphisms with thermo tolerance traits and tissue specific expression in Chinese Holstein cattle. Molecular Biology Reports 38:2657-2663.

Li, Q. L.; Ju, Z. H.; Huang, J. M.; Li, J. B.; Hou, M. H.; Wang, C. F. and Zhong, J. F. 2011. Two novel SNPs in HSF1 gene are associated with thermal tolerance traits in Chinese Holstein cattle. DNA and Cell Biology 30:247-254.

Liu, Y.; Daqi, L.; Huixia, L.; Xuan, Z. and Wang, G. 2010. A novel SNP of the ATP1A1 gene is associated with heat tolerance traits in dairy cows. Molecular Biology Reports 38:83-88. 
McKay, S. D.; Robert, D. S.; Brenda, M. M.; Lakshmi, K. M.; Jan, A.; Wouter, C.; Denny, C.; Emmanuel, D. N.; Clare, A. G.; Chuan, G.; Hideyuki, M.; Paul, S.; Zhiquan, W.; Curt, P. V. T.; John, L. W.; Jeremy, F. T. and Stephen, S. M. 2007. Whole genome linkage disequilibrium maps in cattle. BMC Genetics 8:74.

Mohanarao, J. C. G.; Mukherjee, A.; Banerjee, D.; Gohain, M.; Dass G.; Brahma, B.; Datta, T. K. D.; Upadhyay, R. C. and De, S. 2013. HSP70 family genes and HSP27 expression in response to heat and cold stress in vitro in peripheral blood mononuclear cells of goat (Capra hircus). Small Ruminant Research 116:94-99.

Monzo, C.; Haouzi D.; Roman, K.; Assou, S.; Dechaud, H. and Hamamah, S. 2012. Slow freezing and vitrification differentially modify the gene expression profile of human metaphase II oocytes. Human Reproduction 27:2160-2168.

Ott, J. 1992. Strategies for characterizing highly polymorphic markers in human gene mapping. American Journal of Human Genetics 51:283-290.

Parmley, J. L.; Chamary, J. and Hurts, L. D. 2006. Evidence for purifying selection against synonymous mutations in mammalian exonic splicing enhancers. Molecular Biology and Evolution 23:301-309.

Regitano, L. C. A. and Coutinho, L. L. 2001. Biologia molecular aplicada à produção animal. Embrapa Informação Tecnológica, Brasília.

Rosenkrans, C. J.; Banksa, A.; Reitera, S. and Looperb, M. 2010. Calving traits of crossbred Brahman cows are associated with heat shock protein 70 genetic polymorphisms. Animal Reproduction Science 119:178-182.

Salces-Ortiz, J.; González, C.; Moreno-Sánchez, N.; Calvo, J. H.; Perez-Guzmán, M. D. and Serrano, M. M. 2013. Ovine HSP90AA1 expression rate is affected by several $S N P \mathrm{~S}$ at the promoter under oth basal and heat stress conditions. PLoS One 8(6):e66641.

Scharf, B.; Carroll, J. A.; Riley, D. G; Chase Jr., C. C.; Coleman, S. W.; Keisler, D. H.; Weaber, R. L. and Spiers, D. E. 2010. valuation of physiological and blood serum differences in heattolerant (Romosinuano) and heat-susceptible (Angus) Bos taurus cattle during controlled heat challenge. Journal of Animal Science 88:2321-2336.

Schwerin, M.; Maak, S.; Kalbe, C. and Fuerbass, R. 2001. Functional promoter variants of highly conserved inducible hsp70 genes significantly affect stress response. Biochimica et Biophysica Acta 1522:108-111.

Schwerin, M.; Maak, S.; Hagendorf, A.; Lengerken, G. and Seyfert, H. M. 2002. A 3'UTR variant of the inducible porcine HSP70.2 gene affects mRNA stability. Biochimica et Biophysica Acta 1578:90-94.

Schwerin, M.; Sanftleben, H. and Grupe, S. 2003. Genetic predisposition for productive life is associated with functional inactivation of a AP2-binding site in the promoter of the stress protein 70.1-encoding gene in cattle. Archiv Fur Tierzucht 46:177-185.

Silva, R. G. 2000. Introdução a bioclimatologia animal. Nobel, São Paulo. 286p.

Singh, R.; Kølvraa, S.; Bross, P.; Jensen, U. B.; Gregersen, N.; Tan, Q.; Knudsen, C. and Rattan, S. I. S. 2006. Reduced heat shock response in human mononuclear cells during aging and its association with polymorphisms in HSP70 genes. Cell Stress and Chaperones 11:208-215.

Starkey, L.; Looper, M. L.; Banks, A.; Reiter, S. and Rosenkrans, C. J. 2007. Identification of polymorphisms in the promoter region of the bovine heat shock protein gene and associations with bull calf weaning weight. American Society of Animal Science, Southern Section Meeting 85:42.

Tizioto, P. C.; Gasparin, G.; Souza, M. M.; Mudadu, M. A.; Coutinho, L. L.; Mourão, G. B.; Tholon P.; Meirelles, S. L. C.; Tullio, R. R.; Rosa, A. N.; Alencar, M. M.; Medeiros, S. R.; Siqueira, F.; Feijó, G. L. D.; Nassu, R. T. and Regitano, L. C. A. 2013. Identification of $K C N J 11$ as a functional candidate gene for bovine meat Tenderness. Physiological Genomics 45:1215-1221.

Zan, L. S.; Zhang, J. L. and Liu, X. W. 2007. Association study on AGPAT6 intron3 polymorphism and milk performance of dairy cattle. Scientia Agricultura Sinica 40:1498-1503.

Zhang, X.; Du, H. and Li, J. 2002. Single nucleotide polymorphism of chicken heat shock protein (HSP70) gene. In: 7th World Congress on Genetics Applied to Livestock Production, France, Montpellier.

Zimin, A. V.; Delcher, A. L.; Florea, L.; Kelley, D. R.; Schatz, M. C.; Daniela, P.; Hanrahan, F.; Pertea, G.; Tassell, C. P. V.; Sonstegard, T. S.; Marçais, G.; Roberts, M.; Subramanian, P.; Yorke, J. A. and Salzberg, S. L. 2009. A whole-genome assembly of the domestic cow Bos taurus. Genome Biology 10:42. 